\title{
AHORRO INFANTIL, UN ACERCAMIENTO A LA INCLUSIÓN FINANCIERA. CHISPITAS DE LA FUNDACION AYÚ, OAXACA, MÉXICO
}

\section{CHILDREN'S SAVINGS, AN APPROACH TO FINANCIAL INCLUSION: CHISPITAS FROM THE FUNDACIÓN AYÚ, OAXACA, MÉXICO}

\author{
Guadalupe Arcos-Medina, Oliverio Hernández-Romero*, Emma Zapata-Martelo
}

\begin{abstract}
Desarrollo Rural. Colegio de Postgraduados, Carretera Federal México-Texcoco Km. 36.5, Montecillo Estado de México. 56230. (garcos@colpos.mx) (ohr@colpos.mx)(emmazm@ yahoo.com.mx)
\end{abstract}

RESUMEN

Las microfinanzas han puesto énfasis en los microcréditos, dejando de lado otros elementos de los servicios financieros como el ahorro en las familias pobres, y prácticamente ignorando la presencia y participación de nińas y niños en esquemas como las cajas de ahorro. En el artículo se analiza la operación de dos cajas de ahorro como parte de la estrategia de combate a la pobreza de la Fundación Ayú en la Mixteca Oaxaqueńa, que permite, fomenta y estimula el ahorro infantil, contribuyendo a la inclusión financiera de niños, niñas y adolescentes. La investigación se realizó en el municipio de San Francisco Jaltepetongo, Oaxaca. La metodología utilizada se basó en la aplicación de un cuestionario, entrevistas y un taller de educación financiera. Los resultados indican que la presencia y el ejemplo de las madres en las cajas son la principal influencia para que niños y niñas ahorren; además, de manera empírica, distinguen entre deseos y necesidades, base para una futura educación financiera, por lo que sus ahorros tienen objetivos específicos que ellos mismos deciden. La conclusión es que nińos y nińas comienzan a relacionarse con términos como préstamo, interés, manejo de dinero, lo que los aproxima a ser incluidos financieramente, fuera de la banca formal.

Palabras clave: ahorro, cajas de ahorro, mixteca, préstamos.

\section{INTRODUCCIÓN}

E n México, el organismo que regula la operación de las entidades integrantes del sistema financiero, la Comisión Nacional Bancaria y de Valores (CNBV, 2015) precisa que la inclusión financiera significa "acceso y uso de una gama de productos y

* Autor responsable * Author for correspondence.

Recibido: marzo, 2015. Aprobado: diciembre, 2015.

Publicado como ARTÍCULO en ASyD 13: 473-492. 2016.

\section{Abstract}

Microfinances have placed an emphasis on microcredits, leaving aside other elements of financial services such as savings in poor families, and virtually ignoring the presence and participation of girls and boys in schemes such as the savings funds. The article analyzes the operation of two savings funds as part of the strategy used to combat poverty, by Fundación Ayú, in the Mixtec Region of Oaxaca, which allows, promotes and stimulates children's savings, contributing to the financial inclusion of boys, girls and teenagers. The study was carried out in the municipality of San Francisco Jaltepetongo, Oaxaca. The methodology used was based on the application of a questionnaire, interviews and a financial education workshop. Results indicate that the presence and example of mothers in the savings funds are the principal influence for boys and girls to save; also, empirically, they distinguish between desires and needs, a basis for future financial education, so their savings have specific objectives that they decide for themselves. The conclusion is that boys and girls begin to relate with terms such as loan, interest, money management, which brings them closer to being financially included, outside formal banking.

Key words: savings, savings funds, Mixtec region, loans.

\section{INTRODUCTION}

$\mathrm{I}$ n México, the organization that regulates the operation of the entities that comprise the financial system, the National Banking and Values Commission (Comisión Nacional Bancaria $y$ de Valores, CNBV, 2015), specifies that financial inclusion means "access and use of a range of financial products and services by the population, under an appropriate regulation that oversees the interests of the system's users and promotes their financial 
servicios financieros por parte de la población, bajo una regulación apropiada que cuida los intereses de los usuarios del sistema y fomenta sus capacidades financieras". El Consejo Nacional de Inclusión financiera (CNIF, 2013) señala que la inclusión financiera (IF) considera cuatro dimensiones primordiales i) acceso, referido a la infraestructura financiera disponible para ofrecer servicios y productos financieros, como son sucursales, cajeros automáticos, terminales puntos de venta, entre otros; ii) uso, relacionado con el número de productos financieros disponibles accesibles para las y los usuarios, como son cuentas de ahorro, de cheques, de nómina, depósitos, tarjetas de crédito, variedad de créditos y seguros, principalmente; iii) educación financiera, que aborda el conocimiento sobre los servicios y productos financieros y su uso responsable y, finalmente, iv) protección al consumidor, a través de la creación de situaciones de equidad entre los usuarios y los proveedores de servicios financieros. Sin embargo, todos estos elementos no satisfacen a cabalidad las necesidades de la población en general, situación que se exacerba de manera específica cuando se trata de comunidades rurales en condiciones de pobreza y marginación. Botones de muestra son las cifras para el estado de Oaxaca que cuenta con 1.34 sucursales por cada 10000 habitantes, comparadas con un promedio nacional de 4.76. Además, en 417 de sus 570 municipios no tiene un solo canal de acceso bancario, ya sea con sucursales o corresponsales.

Lo confirma Campos (2005) en su estudio, donde precisa que una persona de bajos ingresos que habite en el norte del país, en poblaciones de más 500000 habitantes, tiene una probabilidad dos veces mayor de usar bancos que si vive en una ciudad pequeña o en comunidades rurales. En el sur del país las probabilidades de contar con una cuenta bancaria serían aún menores o prácticamente nulas. El nivel de ingresos tiene relación directa con la participación en el sistema financiero, dado que la banca comercial se orienta hacia potenciales clientes de ingresos medios y altos, por lo que los pobres quedan en desventaja (Rutherford, 2002). Además, Mansell (1995) menciona que hay que considerar la centralidad de la infraestructura financiera del país.

Por ello, Esquivel (2008) menciona que más de la mitad de las familias mexicanas, $57 \%$, se ubican al margen de los servicios financieros, principalmente por la falta de adecuación de los productos y servicios capacities". The National Council for Financial Inclusion (Consejo Nacional de Inclusión Financiera, CNIF, 2013) states that financial inclusion (FI) considers four primordial dimensions: i) access, referring to the financial infrastructure available to offer financial services and products, such as branch offices, ATMs, sales points terminals, among others; ii) use, related to the number of financial products available that are accessible for users, such as savings, checks, payroll accounts, deposits, credit cards, variety of credits and insurance, primarily; iii) financial education, which addresses knowledge of financial services and products, and their responsible use; and, finally, iv) consumer protection, through the creation of situations of equity between users and providers of financial services. However, all these elements do not satisfy fully the needs of the general population, situation that is exacerbated specifically when the issue at hand is rural communities under conditions of poverty and marginalization. Examples of this are the figures for the state of Oaxaca, which has 1.34 branch offices for every 10000 inhabitants, compared to a national average of 4.76. In addition, in 417 of its 570 municipalities, there is not a single banking access channel, whether through branch offices or correspondents.

Campos (2005) confirms it in his study, where he details that a person of low income who resides in the north of the country, in populations of over 500000 inhabitants, has a probability of using banks twice higher than if he/she lives in a small city or in a rural community. In the south of the country, the probabilities of having a bank account would be even lower or practically null. The level of income has a direct relationship with participation in the financial system, given that the commercial bank is directed at potential clients of medium and high income, which is why the poor remain at a disadvantage (Rutherford, 2002). In addition, Mansell (1995), mentions that the centrality of the financial infrastructure of the country must be considered.

Therefore, Esquivel (2008) says that more than half of the Mexican families, $57 \%$, are outside the margin of financial services, primarily because of the lack of adaptation of the products and services offered to them. The prior idea is crystallized with the opinion of Heimann et al. (2009) when they state that: "as the products and services offered are adapted to the needs of the population their level of use will 
que se les ofrecen. La idea anterior se concreta con la opinión de Heimann et al. (2009) al afirmar que "en la medida que los productos y servicios ofrecidos sean adecuados a las necesidades de la población se favorecerá su nivel de utilización, contribuyendo a una mayor eficiencia y rentabilidad de los intermediarios financieros que los ofrecen".

El Centro para la Inclusión Financiera en ACCION International (2009) argumenta que la importancia de que las personas sean acogidas financieramente radica en que la IF tiene potencial para contribuir a la economía familiar con efecto en la economía del país, así como a reducir la desigualdad social. Un aspecto de mayor impacto es que los servicios financieros, bien utilizados, pueden influir en mejorar la calidad de vida y la productividad de los micro-emprendimientos de los hogares de bajos ingresos que tengan acceso a estos servicios.

Los datos obtenidos por De la Madrid (2012) en el Reporte sobre la discriminación en México 2012, en el tema del crédito, arrojan que el sistema financiero mexicano excluye a muchas personas por muchas razones, pero la principal es por la clase social, ya sea por razones de ingresos o de identidad. Las principales barreras y causas de la discriminación son la informalidad, la incapacidad para demostrar ingresos y la situación de irregularidad de las propiedades o activos que pudieran ofrecerse como garantía, aunado a una insuficiente cultura financiera. Por segmento de la población, las mujeres en específico, sobre todo las pobres y localizadas en zonas rurales, eran marginadas por esa condición. Recientemente las mujeres han empezado a ser valoradas por el sistema financiero, por considerarlas como más responsables y pagadoras, por lo que se han convertido en el nicho de mercado favorito de los microcréditos. Otro segmento que ha sido relegado es el de los jóvenes y las personas adultas, estas últimas por la dificultad de comprobar ingresos y ofrecer colaterales; casi todas las instituciones bancarias se niegan a prestar recursos a personas mayores de 60 años. Para el caso de los jóvenes, también se ven afectados por encontrarse generalmente en trabajos informales que, además, tienen remuneraciones bajas; niños, niñas y adolescentes son considerados como objeto de atención solo por algunos bancos y casi exclusivamente en zonas urbanas. De la Madrid (2012) resume esta situación con una reflexión: "Un sistema financiero que no es capaz de encontrar mecanismos de financiamiento para las poblaciones más jóvenes, es decir, be favored, contributing to a higher efficiency and profitability of the financial intermediaries that offer them".

The Center for Financial Inclusion at International ACCION (Centro para la Inclusión Financiera en ACCION International, 2009) argues that the importance of people being accepted financially lies in that FI has the potential of contributing to the family economy with an effect on the country's economy, as well as reducing social inequality. An aspect of greater impact is that financial services, when used properly, can have an influence in improving the quality of life and productivity of the micro-enterprises of the lowincome households that have access to these services.

The data obtained by De la Madrid in the Report on Discrimination in México 2012, in the subject of credit, show that the Mexican financial system excludes many people for many reasons, although the main one is social class, whether for reasons of income or of identity. The principal barriers and causes of discrimination are informality, the inability to demonstrate income, and the situation of irregularity of properties or assets that could be offered as guarantee, in addition to an insufficient financial culture. By segment of the population, women specifically, particularly the poor and who reside in rural areas, were marginalized by this condition. Recently, women have begun to be valued by the financial system, because they are considered to be more responsible and prompt in paying, so they have become the favorite market niche of microcredits. Another segment that has been relegated is that of youth and adults, the latter because of the difficulty to demonstrate income and offer collateral; almost all bank institutions refuse to lend resources to people over 60 years. For the case of young people, they are also affected because they generally perform informal jobs, which, in addition, have low pay; boys, girls and teenagers are considered an object of attention only by some banks and almost exclusively in urban zones. De la Madrid (2012) sums up this situation with a reflection: "A financial system that is not capable of finding financing mechanisms for younger populations, that is, which cannot take risks in favor of this sector of the community, will tend to have an elderly population that never managed to save, develop or have sufficient economic backing for retirement. In contrast, the societies that have understood how to accompany their younger 
que no puede tomar riesgos a favor de este sector de la comunidad, tenderá a contar con una población adulta mayor que nunca logró ahorrar, desarrollarse ni contar con un respaldo económico suficiente para su jubilación. En contraste, las sociedades que han sabido acompañar a sus poblaciones más jóvenes en el despegue económico de sus vidas son aquellas que hoy se encuentran entre las más desarrolladas del mundo". Otros segmentos de la población excluidos del sistema financiero son las personas pertenecientes a comunidades indígenas y las personas con alguna discapacidad.

En este artículo se analiza cómo las microfinanzas, a través de la operación de dos cajas de ahorro, pueden convertirse en elemento importante para el fomento y creación del hábito del ahorro de niños y niñas, y permitir su inclusión financiera a futuro, a través de tres variables: quién les enseña a ahorrar, cómo perciben la diferencia entre deseos y necesidades, y cómo su participación en las cajas las y los visibiliza ante su comunidad. La hipótesis asumida en el trabajo es que son las madres quienes ejercen la mayor influencia en la formación del hábito del ahorro, con implicaciones en su educación e inclusión financiera.

\section{ABORDAJE TEÓRICO: AHORRO PARA ACUMULACIÓN DE ACTIVOS EN CONDICIONES DE INCERTIDUMBRE, EL PROCESO EDUCATIVO Y LA EDUCACIÓN FINANCIERA}

Tomando como punto de partida la pregunta de cómo salir de la pobreza, sin duda una posible respuesta es a través del ahorro y la acumulación de activos, ya sean estos humanos, físicos, financieros o sociales (Sherraden et al., 2001). Analizar la importancia de la acumulación de activos físicos y financieros de las familias pobres tiene tres elementos importantes; el primero porque contar con este tipo de activos permite participar en una economía de mercado; segundo, porque la desigual distribución y el acceso asimétrico a esos activos puede contribuir a reproducir la condición de pobreza, y, tercero, porque las familias que cuentan con esta clase de activos ven modificado su bienestar, su seguridad económica, e incluso, su comportamiento (Bernal, 2007).

La gente pobre tiene varias estrategias de ahorro, tal y como señala Castillo (2012), en Daryl Collins, Las finanzas de los pobres, al destacar tres descubrimientos populations in the economic takeoff of their lives are those that today are found among the most developed in the world". Other segments of the population excluded from the financial system are people that belong to indigenous communities and people with disabilities.

This article analyzes how microfinances, through the operation of two savings funds, can become an important element for the promotion and creation of the habit of saving in boys and girls, allowing their financial inclusion in the future, through three variables: who teaches them to save, how they perceive the difference between wishes and needs, and how their participation in savings funds makes them visible to their community. The hypothesis assumed in the study is that it is the mothers who exert the greatest influence in the formation of the habit of saving, with implications in their financial education and inclusion.

\section{THEORETICAL APPROACH: SAVING FOR ACCUMULATION OF ASSETS UNDER CONDITIONS OF UNCERTAINTY, THE EDUCATIONAL PROCESS AND FINANCIAL EDUCATION}

Taking as starting point the question of how to get out of poverty, without a doubt a possible response is through savings and the accumulation of assets, whether they are human, physical, financial or social (Sherraden et al., 2001). Analyzing the importance of the accumulation of physical and financial assets by poor families includes three important elements; first, because having this type of assets allows participating in a market economy; second, because unequal distribution and asymmetrical access to these assets can contribute to reproducing the condition of poverty; and, third, because the families that have this kind of assets see their wellbeing, economic security, and even their behavior, changed (Bernal, 2007).

Poor people have several savings strategies, as pointed out by Castillo (2012) in Daryl Collins, Portfolios of the Poor, by highlighting three outstanding discoveries. 1) The poor are the most important actors to decrease poverty; they make daily efforts to help themselves in an active way. External actors support these processes, but they are not defining in this struggle. 2) The poor use financial tools in an active manner, not in spite of being poor, but rather precisely because they are poor; they have designed 
sobresalientes. 1) Los pobres son los actores más importantes para disminuir la pobreza; ellos y ellas hacen esfuerzos cotidianos para ayudarse a sí mismos en forma activa. Los actores externos apoyan estos procesos, pero no son determinantes en esta lucha. 2) Los pobres utilizan herramientas financieras de manera activa, no a pesar de ser pobres, sino justamente porque son pobres; ellos y ellas han diseñado y encontrado alternativas para manejar su escaso dinero. En su investigación encontraron que usan un promedio de 10 instrumentos financieros distintos al año, diversificación que responde a necesidades y oportunidades diferentes. 3) Los pobres "administran" el dinero ahorrando cuando pueden y pidiendo prestado cuando es necesario. Los autores arriban a una conclusión clave: la demanda de un lugar para ahorrar es infinitamente mayor que la de obtener crédito.

La Organización de las Naciones Unidas para la Agricultura y la Alimentación, FAO (por sus siglas en inglés, 2013), reporta que los pobres tienen varias maneras de ahorrar. La primera es en especie; normalmente lo hacen guardando cereales alimenticios, como maíz o arroz, o en ganado, como vacas, cerdos, cabras o gallinas y, en ocasiones, en artículos como joyas, oro u otros bienes, cuyo valor aumenta y permiten venderlos fácilmente en el futuro para obtener dinero. La segunda manera es el ahorro en dinero, ya sea en casa o en alguna institución, ya que casi todas las personas, incluidas las muy pobres, tienen necesidad de manejar dinero para su vida cotidiana. Las principales ventajas de este tipo de ahorro son que éste es fácil de llevar, almacenable, poco visible y tiene la ventaja de ser fungible, es decir, puede utilizarse para muchos fines.

Un tercer tipo de ahorro es dando algo; la gente hace regalos $\mathrm{u}$ ofrece servicios no solo por generosidad, sino también a veces con la esperanza de que se le devuelva el favor cuando lo necesite. Un ejemplo de este tipo de ahorro es el tequio, tradicional en muchas regiones rurales.

En palabras de Bazán y Saraví (2012) las finanzas populares incluyen una gran cantidad de actos pequeños, amplios y heterogéneos realizados por los hogares de bajos ingresos con el fin de enfrentar la subsistencia diaria, mejorar el bienestar de la familia o para responder a necesidades y riesgos imprevistos que se acrecientan debido a la vulnerabilidad de sus ingresos. Dentro de las estrategias que desarrollan se incluye el trabajo de niños y niñas, empleo formal, and found alternatives to manage their scarce money. In their research, the authors found that they use an average of 10 different financial instruments per year, diversification that responds to different needs and opportunities. 3) The poor "manage" money by saving when they can and asking for loans when necessary. The authors arrive at a key conclusion: the demand for a place for savings is infinitely higher than the demand for obtaining credit.

The Food and Agriculture Organization of the United Nations (FAO, 2013) reports that the poor have several ways of saving. The first is in species; normally they do it by storing food cereals, such as maize or rice, or in livestock, such as cows, pigs, goats or hens, and, occasionally, in articles such as jewels, gold or other goods, whose value increases and allows them to be sold easily in the future to obtain money. The second way is saving money, whether at home or in an institution, since almost all people, included the very poor, have the need to manage money for their daily life. The main advantages of this type of savings are that it is easy to carry out, store, scarcely visible, and has the advantage of being fungible; that is, it can be used for many purposes.

A third type of saving is giving something; people make gifts or offer services not only out of generosity, but also sometimes with the hope of the favor being returned when needed. An example of this type of saving is the tequio, traditional in many rural regions.

In the words of Bazán and Saraví (2012), popular finances include a large amount of small, broad and heterogeneous acts carried out by the households of low income with the aim of facing the daily subsistence, improving the family's welfare, or responding to needs and unforeseen risks that grow due to the vulnerability of their income. Within the strategies developed, they include work by boys and girls, formal employment, self-employment, microenterprises, and, therefore, different ways of saving, such as those exposed before.

Assuming that boys, girls and young people are social and economic actors in the present and in the future, whose decisions will influence the development of their societies, it turns out to be important to understand how it is that boys, girls and teenagers learn to save. In this regard, taking up Piaget, Amar et al. (2003) mention that from the constructivist perspective, it is held that girl and boys are active individuals who build on their own 
autoempleo, micro-negocios y, por consiguiente, diferentes formas de ahorro como las expuestas anteriormente.

Asumiendo que niños, niñas y jóvenes son actores sociales y económicos en el presente y en el futuro, cuyas decisiones influirán en el desarrollo de sus sociedades, resulta importante conocer cómo es que niños, niñas y adolescentes aprenden a ahorrar. A ese respecto, retomando a Piaget, Amar et al (2003) comentan que desde la perspectiva constructivista se sostiene que la niña y el niño son individuos activos que construyen por sí mismos tanto sus propios conocimientos como la forma en que los organizan. En este proceso de construcción de representaciones, el ambiente social actúa como el suministrador de experiencias y aporta los contenidos que caracterizarán a la representación, pero la forma en que el sujeto organice estos elementos será mediada por el nivel de desarrollo de sus estructuras cognitivas.

De esta manera, Delval (1989) propone algunos de los componentes relevantes que integran las representaciones que niños, niñas y adolescentes elaboran acerca de la realidad. Estas son identificadas en cuatro rubros: normas, valores, informaciones y explicaciones. Las tres primeras son influenciadas en gran medida por los padres y la misma familia, mientras que en el tema de las explicaciones acerca del porqué de las cosas está casi ausente de la trasmisión social y niños y niñas se ven obligados a construirlas con las herramientas intelectuales de que disponen.

Estos actores y actrices sociales comienzan a relacionarse con la realidad económica desde sus primeros años de vida, a partir de experiencias tan cotidianas como ir a la tienda, al mercado o escuchar a sus padres y a otros adultos sobre «lo económico» o sobre el precio de los productos que compran en los comercios. Esto les obliga a un esfuerzo constante por construirse modelos explicativos de esta realidad tan cercana, pero a la vez tan compleja y difícil de abordar.

\section{El proceso educativo}

La transmisión de la cultura que las generaciones adultas realizan a los jóvenes es lo que se denomina educación (Delval, 1983). Desde el nacimiento, e incluso desde antes, nińos y nińas están sometidos a la influencia de la sociedad en la que viven. Mediante esta presión social, llegan a constituirse en miembros de ésta, adquiriendo las pautas de conducta que son both their understandings and the way in which they are organized. In this process of representation construction, the social environment acts like the supplier of experiences and contributes the contents that will characterize the representation, although the way in which the subject organizes these elements will be mediated by the level of development of their cognitive structures.

Therefore, Delval (1989) suggests some of the relevant components that make up the representations that boys, girls and teenagers make regarding reality. These are identified in four aspects: rules, values, information and explications. The first three are influenced to a great degree by the parents and the family itself, while the issue of explanations regarding the cause of things is almost absent from the social transmission, and boys and girls are forced to build them with the intellectual tools that they have available to them.

These social actors begin to relate to the economic reality since their first years of life, from such everyday experiences as going to the store, to the market, or listening to their parents and other adults speak about "the economic scope" or about the price of the products they purchase at shops. This forces them to make a constant effort to build for themselves explicative models of this reality, which is so close yet at the same time so complex and difficult to approach.

\section{The educational process}

The transmission of culture that adult generations carry out towards young people is what is called education (Delval, 1983). Since birth, and even before, boys and girls are subjected to influence from the society that they live in. Through this social pressure, they become constituted into members of it, acquiring the guidelines for behavior that are characteristic of it, and they will learn to behave as adults in that society, with their language and the whole of culture.

The educational process is performed in multiple ways, in the family, in the street, and in school. Through contact with other individuals and with the surrounding world, they become imbued with social influence. Through it characteristics are acquired that are common to all, men and women, in all times; those that are considered human and other more specific ones that can be characteristic of a nation, of 
características de ella, y aprenderán a comportarse como los adultos de esa sociedad, con su lenguaje y el conjunto de la cultura.

El proceso educativo se realiza de múltiples maneras, en la familia, en la calle, en la escuela. A través del contacto con otros individuos y con el mundo circundante se van impregnando de la influencia social. Mediante esta se adquieren características que son comunes a todos, hombres y mujeres, en todas las épocas; las que se consideran humanas y otras más específicas que pueden ser propias de una nación, de una ciudad, de una clase social, de un pequeño grupo, o de una familia. Pero, en todo caso, esa transmisión tiene una misión conservadora del orden existente, pues los adultos tienden a reproducirse en los niños, no solo en el sentido biológico, sino también en el cultural.

El amplio crecimiento en la oferta de servicios financieros, formal e informal, está generando un fuerte desequilibrio entre los proveedores y los usuarios, derivado de la baja educación financiera de los últimos. Actualmente, Carbajal (2008) menciona que dentro de la realidad de los pobres, en la que las desigualdades de información constituyen una norma, el desarrollo que ha experimentado el mercado financiero los está llevando a comprender cada vez menos las nuevas opciones que hay a su disposición y, por tanto, es probable que no las usen en su beneficio o, peor aún, los aleje del sistema formal.

La OECD (2005) define a la educación financiera como "el proceso por el cual los consumidores financieros e inversores mejoran su comprensión de los productos y conceptos financieros a través de información, instrucción o consejo objetivo, desarrollan habilidades y confianza para conocer mejor los riesgos y oportunidades financieras, tomar decisiones informadas, saber dónde obtener ayuda y tomar otras decisiones efectivas que les permitan mejorar su condición financiera."

Coates (2009) ha destacado que en el transcurso de la existencia de las personas se dan "situaciones didácticas" en las que se encuentran más receptivos a la educación financiera; por ejemplo, en la niñez, en la etapa universitaria o el matrimonio, por lo que se hace necesario iniciar la alfabetización financiera en las primeras etapas de vida, debido a que cada vez existen más productos financieros, son más variados, complejos y sofisticados, por lo que es necesario que los padres inculquen el hábito del ahorro, para que a city, of a social class, of a small group, or of a family. However, in any case, this transmission has a mission to conserve the existing order, since the adults tend to reproduce themselves in the children, not just in the biological sense but also in the cultural one.

The broad growth in the offer of financial services, formal and informal, is generating a strong imbalance between suppliers and users, derived from the low financial education of the latter. Currently, Carbajal (2008) mentions that within the reality of the poor, where imbalances of information constitute the norm, the development that the financial market has experienced is leading them to understand increasingly less the new options available to them and, therefore, it is likely that they do not use them to their benefit or, worse still, that they distance them from the formal system.

The OECD (2005) defines financial education as "the process by which financial consumers and investors improve their understanding of financial products and concepts through information, instruction or objective advise, develop abilities and confidence to comprehend better the financial risks and opportunities, make informed decisions, know when to obtain help and make other effective decisions that allow them to improve their financial condition".

Coates (2009) has highlighted that in the length of a person's existence, "didactic situations" take place, where they are more receptive to financial education; for example, during childhood, in the university or marriage stage, so it becomes necessary to begin the financial literacy in the first stages of life, since there are increasingly more financial products, they are more varied, complex and sophisticated, which is why it is necessary for parents to instill the habit of saving, so that when they reach the adult age they can see it as something natural. Therefore, financial education will allow boys, girls and teenagers to acquire the habit of saving and to better understand the options offered by suppliers of financial services.

\section{Methodology}

\section{Study region}

The state of Oaxaca represents $4.8 \%$ of the total national surface, occupying the fifth place in the country; it is made up of 570 municipalities, 
al llegar a la edad adulta lo vean como algo natural. De esta manera, la educación financiera les permitirá a niños, niñas y adolescentes adquirir el hábito del ahorro y entender de mejor manera las opciones que ofertan los proveedores de servicios financieros.

\section{Metodología}

\section{La región de estudio}

El estado de Oaxaca representa $4.8 \%$ de la superficie total nacional, ocupando el quinto lugar del país, se integra por 570 municipios, casi tres cuartas partes del total de municipios de toda la república mexicana. Es el estado con la mayor diversidad étnica y lingüística de México. En el actual territorio oaxaqueño conviven 18 grupos étnicos de los 65 que hay en el ámbito nacional: mixtecos, zapotecos, triquis, mixes, chatinos, chinantecos, huaves, mazatecos, amuzgos, nahuas, zoques, chontales de Oaxaca, cuicatecos, ixcatecos, chocholtecos, tacuates, afromestizos de la costa chica y en menor medida tzotziles, que en conjunto superan el millón de habitantes, alrededor de $34.2 \%$ del total del estado, distribuidos en 2563 localidades (Página oficial del gobierno del estado de Oaxaca, administración 2010-2016).

En uno de los municipios del estado de Oaxaca surge la Fundación Ayú, que desde su origen ha buscado integrar recursos y esfuerzos para combatir la pobreza en la mixteca, una de las ocho regiones del estado, ubicada al norte de Oaxaca.

La región de la mixteca oaxaqueña colinda con los estados de Puebla y Guerrero, con la región de la cañada, al este; con Los Valles Centrales, al sureste; y con la Sierra Sur, al sur. En Oaxaca, la mixteca ocupa 189 municipios de 14 distritos.

El Consejo Nacional de Población (Conapo, 2010) reporta que Oaxaca ocupa el tercer lugar en el ámbito nacional, clasificado con un nivel de muy alta marginación. El municipio en que se llevó a cabo la investigación, San Francisco Jaltepetongo, está ubicado en un nivel de marginación media, con un total de 1110 habitantes, según el Instituto de Estadística, Geografía e Informática, (INEGI, 2012).

Desde hace más de 15 años la Fundación Ayú ha promovido la integración de cajas de ahorro en las comunidades, ya que dentro de la estrategia de desarrollo rural y combate a la pobreza que implementó, las cajas fueron el eje alrededor del cual giraba y las almost three fourths of the total of municipalities in the whole Mexican republic. It is the state with the greatest ethnic and linguistic diversity in México. In the current territory of Oaxaca, there are 18 ethnic groups of the 65 in the country: Mixteco, Zapoteco, Triqui, Mixe, Chatino, Chinanteco, Huave, Mazateco, Amuzgo, Nahua, Zoque, Chontal of Oaxaca, Cuicateco, Ixcateco, Chocholteco, Tacuate, Afro-mestizo of the Costa Chica and to a lesser degree Tzotzil, which together are more than a million inhabitants, around $34.2 \%$ of the state total, distributed in 2563 localities (official webpage of the state of Oaxaca, 2010-2016 administration).

In one of the municipalities of the state of Oaxaca, Fundación Ayú was formed, which since its origin has sought to integrate resources and efforts to combat poverty in the Mixtec Region, one of the eight regions of the state, located north of Oaxaca.

The Mixtec Region in Oaxaca adjoins the states of Puebla and Guerrero, with the region of Cañada to the east; with Valles Centrales to the southeast; and with Sierra Sur, to the south. In Oaxaca, the Mixtec Region occupies 189 municipalities of the 14 districts.

The National Population Council (Consejo Nacional de Población, Conapo, 2010), reports that Oaxaca occupies the third place nationwide, classified with a very high level of marginalization. The municipality where the study was performed, San Francisco Jaltepetongo, is located in a medium level of marginalization, with a total of 1110 inhabitants, according to the Institute of Statistics, Geography and Information (Instituto de Estadistica, Geografia e Informática, INEGI, 2012).

Since more than 15 years ago, Fundación Ayú has promoted the integration of savings funds in the communities, since within the strategy of rural development and poverty combat that it implemented, the funds were the axis around which it revolved, and rural women were the ones in charge of training, administration and operation in them.

However, the objective of the banks is not only savings and loans, but rather they go beyond this for they also have the instruction of promoting saving among boys and girls. Therefore, savings funds were created for them that are called Los Chispitas. Boys, girls and teenagers can participate in them, since the moment they are born, represented by their parents, but with accounts and savings cards in their name, 
mujeres rurales fueron las encargadas de la formación, administración y operación de las mismas.

Pero el objetivo de las cajas no es solo el ahorro y el préstamo, sino que va más allá pues también tienen la consigna de fomentar el ahorro para niños y nińas. Por ello, surgen las cajas para ellos llamadas Los Chispitas. En estas pueden participar niños, niñas y adolescentes, desde recién nacidos, representados por sus padres, pero con cuentas y tarjetas de ahorro a su nombre, hasta los de 15 años, edad en la que si deciden continuar ahorrando se incorporan a la caja de las y los adultos.

Los Chispitas tienen un esquema similar a la caja de adultos. Tienen un comité integrado por los socios de la cajita; se reúnen de manera quincenal junto con los adultos. Los padres o las madres de las y los niños del comité los apoyan para administrar la caja, recoger los ahorros de los participantes, anotar en las libretas de ahorro los recursos entregados y, en su momento, cada seis meses, realizar el balance de la operación de la cajita. Cada quincena se contabiliza el monto de recursos que ingresó a la cajita y este dinero se puede ocupar para prestar a los adultos, pagando a nińos y nińas el interés que su dinero haya generado. Los niños y niñas no tienen acceso a préstamos por sí mismos; solo sus padres, integrantes de la caja, pueden acceder a ellos.

Para la investigación se aplicó un cuestionario, se realizó un taller participativo con niños y niñas, así como entrevistas semiestructuradas con informantes clave, como el diseñador de las cajas de ahorro, la promotora que atendió en su origen las cajas, así como las mujeres integrantes de los comités de las cajas del municipio, una con sede en la cabecera municipal, San Francisco Jaltepetongo y la otra en la localidad de San Isidro. Se solicitó a los niños presidentes y secretarios de las cajas, las listas de los integrantes de ambas y, junto con las mamás que apoyan a los comités, se identificó la edad de cada uno de las y los socios. De un universo de 61 socios y socias se aplicó el cuestionario a 42 niños y niñas de ambas localidades, además de ocho entrevistas semiestructuradas a adultos. Los integrantes de las cajas se reúnen los días 15 y 30 de cada mes, por lo que para aplicar el cuestionario se asistió a estas reuniones de 2013 a julio de 2014.

Se revisaron documentos, como las listas de integrantes, libretas de ahorro individual, las libretas de ahorro de las cajas, así como los formatos de los balances semestrales. and up to 15 years old, age at which if they decide to continue saving they are incorporated into the adult funds.

Los Chispitas have a similar scheme to that of the adult savings funds. They have a committee made up of the members of the accounts; they gather every fortnight together with the adults. The mothers or fathers of the committee's children support them to manage the funds, collect the participants' savings, record the resources delivered in the savings bank books and, in time, every six months, carry out the operation balance of the children's funds. Every fortnight the amount of resources that entered the children's funds is counted, and this money can be used to loan it to adults, paying the children the interest that the money generated. The boys and girls do not have access to loans on their own; only their parents, members of the funds, can have access to them.

A questionnaire was applied for the research, and a participative workshop was carried out with boys and girls, as well as semi-structured interviews with key informants, like the designer of the savings funds, the promoter who was responsible for the funds in their origin, and the women members from the municipality's funds committees, one with central offices in the municipal township, San Francisco Jaltepetongo, and another in the locality of San Isidro. The children presidents and secretaries of the funds were asked for the lists of members of both of them, and, together with the mothers who support the committees, the age of each member was identified. From a universe of 61 members, the questionnaire was applied to 42 boys and girls from both localities, in addition to eight semi-structured interviews with adults. The members of the funds gather on days 15 and 30 of every month, so in order to apply the questionnaire we attended these meetings from 2013 to July 2014.

Documents were reviewed, such as the lists of members, individual savings bank books, the fund's savings books, as well as the formats of biannual balances.

\section{Results from the "Chispitas" boys and girls studied}

In the municipality of San Francisco Jaltepetongo, Oaxaca, and its locality of San Isidro, the two Chispitas savings funds are located, with a total of 


\section{Resultados de las niñas y nińos "Chispitas" estudiadas}

En el municipio de San Francisco Jaltepetetongo, Oaxaca y su localidad San Isidro se ubican las dos cajas Chispitas, con un total de 61 integrantes, 41 niños y 20 niñas. En San Francisco son 23 socios y en San Isidro 38, (Figura 1).

Se entrevistaron 42 socios/as que aceptaron participar del trabajo de campo, 13 niñas y 29 niños, 21 en cada localidad, y se realizó un taller participativo sobre educación financiera con la asistencia de 18 Chispitas y siete adultos.

La información socioeconómica obtenida de los entrevistados refleja que la edad promedio es de diez años en las niñas y de 11 años en los niños; la edad máxima para ambos son 15 años, y la mínima cinco para las niñas y ocho para los niños. El nivel de escolaridad se ubica en un rango muy amplio, ya que participan desde los que van al kínder hasta los que cursan tercer ańo de secundaria, es decir, que tienen nueve años de escolaridad. Resalta el hecho de que, en general, el número de niños ahorradores es mayor que el de niñas ahorradoras, y su nivel de años de escolaridad, que está en relación con la edad, también. Algunas madres de familia señalaron que las niñas son más tímidas y a muchas no les interesa participar en las cajas de ahorro. Tampoco ocupan puestos de dirección en la cajita, ni presidente ni secretaria.

El perfil socioeconómico de las familias de niños y niñas Chispitas corresponde a hogares en los que el padre de familia se dedica, en su gran mayoría, al campo (52\%), seguido de los que se dedican a la pirotecnia (fabricación de cohetes), sobre todo en San Francisco, Jaltepetongo (33 \%), mientras que el resto $(14 \%)$ tiene algún oficio o presta algún servicio como chofer. (Figura 2).

La participación de los niños y nińas en las cajas de ahorro los involucra de manera directa con la Fundación Ayú y con la comunidad a la que pertenecen. Por esta razón, se les cuestionó sobre lo que representaba para ellos ser Chispitas y, aun cuando la mayoría no sabe (24), hubo respuestas interesantes, como lo es aprender a ahorrar (12), que es mucho orgullo (4), e incluso, que es una manera de unirse con amigos (2).

Respecto a las actividades de las mamás de los Chispitas, $38 \%$ son amas de casa, mientras que $21 \%$ se dedica a la casa y a labores del campo, y un porcentaje igual adiciona a su trabajo en el hogar la

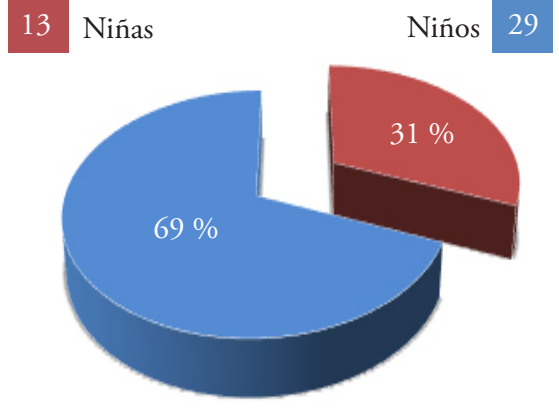

Fuente: trabajo de campo realizado en 2013-2014. * Source: Field work carried out in 2013-2014.

Figura 1. Integración de las cajas por género Figure 1. Integration of funds per gender.

61 members, 41 boys and 20 girls. In San Francisco there are 23 members and in San Isidro, 38 (Figure 1).

Interviews were performed with 42 members who accepted to participate in the field work, 13 girls and 29 boys, 21 in each locality, and a participative workshop was carried out on financial education with the attendance of 18 Chispitas and seven adults.

The socioeconomic information obtained from those interviewed reflects that the average age is ten years in girls and 11 years in boys; the maximum age for both is 15 years, and the minimum five for girls and eight for boys. The level of schooling is located in a very broad range, since those who participate include those who attend kinder garden to those who are in third year of secondary, that is, who have nine years of schooling. The fact stands out that, in general, the number of boys who save is higher than those of girls who save, and their level of schooling, which is in relation to age also. Some mothers pointed out that the girls are more timid and many are not interested in participating in the savings funds. They also do not occupy directing positions in the children's funds, or as president or secretary.

The socioeconomic profile of the families of the Chispitas boys and girls corresponds to households where the parent is devoted, in majority, to the field (52\%), followed by those devoted to pyrotechnics (fireworks manufacture), particularly in San Francisco, Jaltepetongo (33\%), while the rest (14\%) has some trade or offers a service such as chauffeuring (Figure 2). 

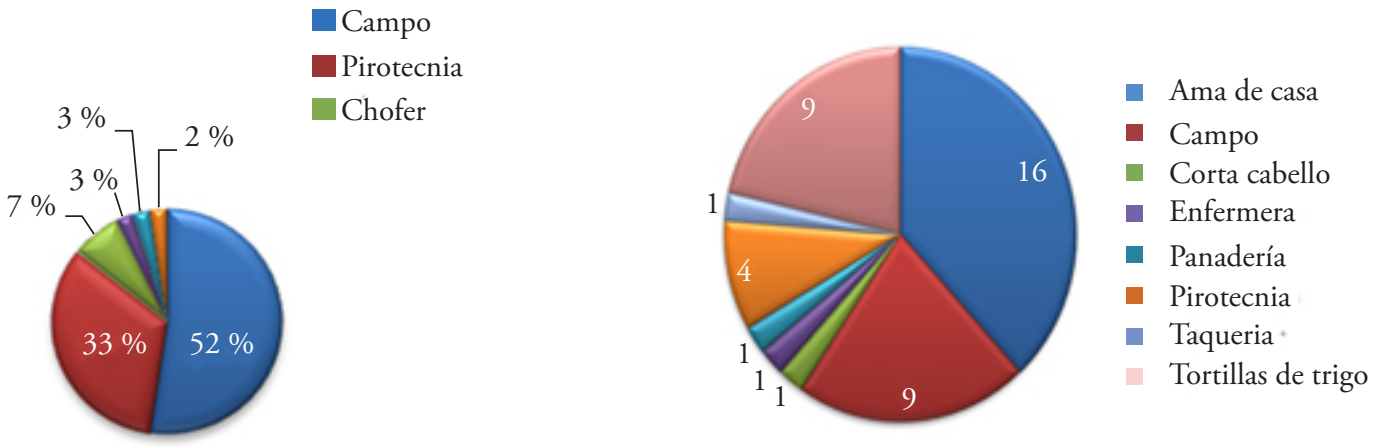

Fuente: trabajo de campo realizado en 2013-2014. Source: field work carried out in 2013-2014.

Figura 2. Ocupación de los padres de los Chispitas

Figure 2. Occupation of parents of the Chispitas members.

fabricación y venta de tortillas de trigo, esto sobre todo en la localidad de San Isidro Jaltepetongo; algunas mujeres también colaboran en la fabricación y en la venta de pirotecnia $(10 \%)$. El menor porcentaje corresponde a algunos oficios variados y sólo en un caso se trata de una profesionista (enfermera).

Para el tema que se analiza fue importante considerar el trabajo de las mujeres, Bazán y Saraví (2012) indican que se caracteriza por ser bastante inestable, asociado con el desarrollo de las trayectorias familiares, muy limitado en el sector rural porque son irregulares los periodos en los que algunas actividades, por las que pueden recibir ingresos, están disponibles y tienen gran volatilidad por los montos recibidos.

Los niños y las niñas tienen desde los tres hasta los siete ańos como ahorradores. Los entrevistados pueden ser comparados con el $1 \%$ de niños que reportan tener una cuenta de ahorro, según datos de la primera encuesta sobre cultura financiera en México BANAMEX-UNAM (2008).

En las familias rurales y pobres es frecuente que niñas y niños colaboren en algunos trabajos que ayudan a los ingresos familiares. De los Chispitas entrevistados, $24 \%$ colabora en trabajos con la familia, principalmente en el campo, en la venta de algunos productos, en la elaboración de cohetes, e incluso en trabajos de albañilería.

Atendiendo a las razones que niños y niñas tienen para ahorrar en las cajitas, una de las respuestas con mayores menciones fue la de guardar para tener dinero en el futuro, seguida de para comprar cosas, pero también hubo otras, como la relativa a que lo destinan a emergencias; asimismo, algunos no saben para qué
The participation of boys and girls in savings funds involves them directly with the Fundación Ayú and with the community that they belong to. For this reason, they were asked about what being Chispitas represented to them and, even when most don't know (24), there were interesting responses, such as learning to save (12), that it is a pride (4), and even, that it is a way to get together with friends (2).

Regarding the activities of mothers of Chispitas members, $38 \%$ are house wives, while $21 \%$ are devoted to the household and field tasks, and an equal percentage adds the elaboration and sale of wheat tortillas to their work in the household, particularly in the locality of San Isidro Jaltepetongo; some women also collaborate in the manufacture and sales of pyrotechnics $(10 \%)$. The least percentage corresponds to some various trades and only in one case there is a professional (nurse).

For the theme being analyzed, it was important to consider the work of women; Bazán and Saraví (2012) indicate that it is characterized by being rather unstable, associated to the development of family trajectories, quite limited in the rural sector because the periods when some activities are available, for which they can receive income, are irregular and have much volatility from the income received.

Boys and girls have three to seven years as savers. Those interviewed can be compared to the $1 \%$ of the children who report having a savings account, according to data from the first survey on financial culture in México BANAMEX-UNAM (2008).

In rural and poor families, it is frequent for girls and boys to collaborate in some tasks that help 
es utilizado, ya que lo administra alguno de los padres. Las respuestas se aprecian en la Figura 3. El testimonio de Nehemías completa la idea.

Mi nombre es Nehemías Noé y vivo en el pueblo de Yucano; camino una hora para venir a la reunión de la cajita. Tengo 10 ańos y estoy en quinto de primaria. Cada quincena ahorro 20 pesos que me da mi mamá. Mi papá me enseñó a ahorrar. Yo estoy ahorrando porque quiero comprarme zapatos, útiles, pagar deudas y ayudar a mi familia a comprar frutas y unos pollos. Creo que es importante ahorrar porque así podemos sacar préstamos (Chispita de la Caja de San Isidro).

Eso no significa que los niños no tengan ideas propias sobre sus ahorros. Por ejemplo, en el taller sobre educación financiera los Chispitas pudieron distinguir la diferencia entre deseos y necesidades, lo cual es importante ya que, aun cuando ellos no conocían la diferencia, esta se identificó al ver que la gran mayoría destinaría su ahorro para su educación o para colaborar con la familia en adquirir alimentos. Los deseos se identificaron claramente al ver que el tema menos importante de su ahorro era la compra de juguetes (Figura 4).

Un dato que resalta es el hecho de que $91 \%$ de los entrevistados respondieron que esperan terminar una carrera y algunos seńalaron que quieren ser maestros, ingenieros/as, licenciados/as, antropólogo/a, e incluso, una criminóloga, y que además piensan seguir

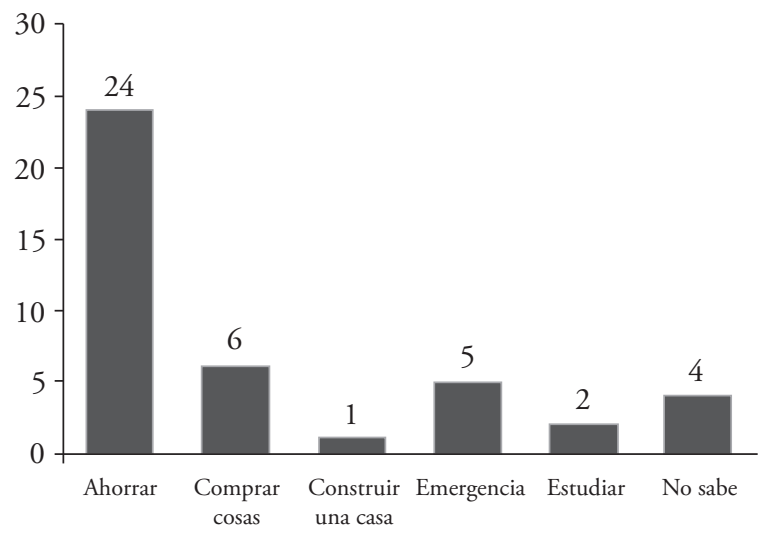

Fuente: trabajo de campo realizado en 2013-2014. * Source: Field work carried out in 2013-2014.

Figura 3. Razones de los Chispitas para ahorrar.

Figure 3. Reason for saving of the Chispitas members. with family income. Of the Chispitas members interviewed, $24 \%$ collaborate in tasks with the family, primarily in the field, in the sale of some products, in the elaboration of fireworks, and even, in brick-laying jobs.

Concerning the reasons why boys and girls have money to save in the children's savings funds, one of the responses more frequently given was setting apart to have money in the future, followed by for the purpose of buying things, although there were also others, such as those who destine it to emergencies; likewise, some don't know what it is used for, since one of the parents manages it. The answers are shown in Figure 3 Nehemías' testimony completes the idea.

My name is Nehemías Noé and I live in the town of Yucano; I walk for one hour to come to the meeting of the children's savings fund. I am 10 years old and I study the fifth grade. Every fortnight I save 20 pesos that my mother gives me. My father taught me to save. I am saving because I want to buy myself shoes, school supplies, to pay debts and to help my family to buy fruits and some chickens. I think it is important to save because that way we can take out loans (Chispitas member from the San Isidro bank).

This doesn't mean that the children do not have their own ideas about their savings. For example, in the workshop on financial education, the Chispitas members were able to tell the difference between wishes and needs, which is important since, even when they didn't understand the variation; it was identified when they saw that most of them would destine their savings to their education or to collaborate with the family to purchase foods. The wishes were clearly identified when they say that the least important theme of their savings was buying toys (Figure 4).

A piece of data that stands out is the fact that $91 \%$ of those interviewed responded that they expect to finish their undergraduate studies and some mentioned that they want to be teachers, engineers, lawyers, anthropologists, and even one girl, a criminologist; and, also, that they intend to keep saving up to the time when they're adults, showing with this how important the savings activity is for them. This situation agrees with what was found by Guevara et al. (2009), who mention that the level of 

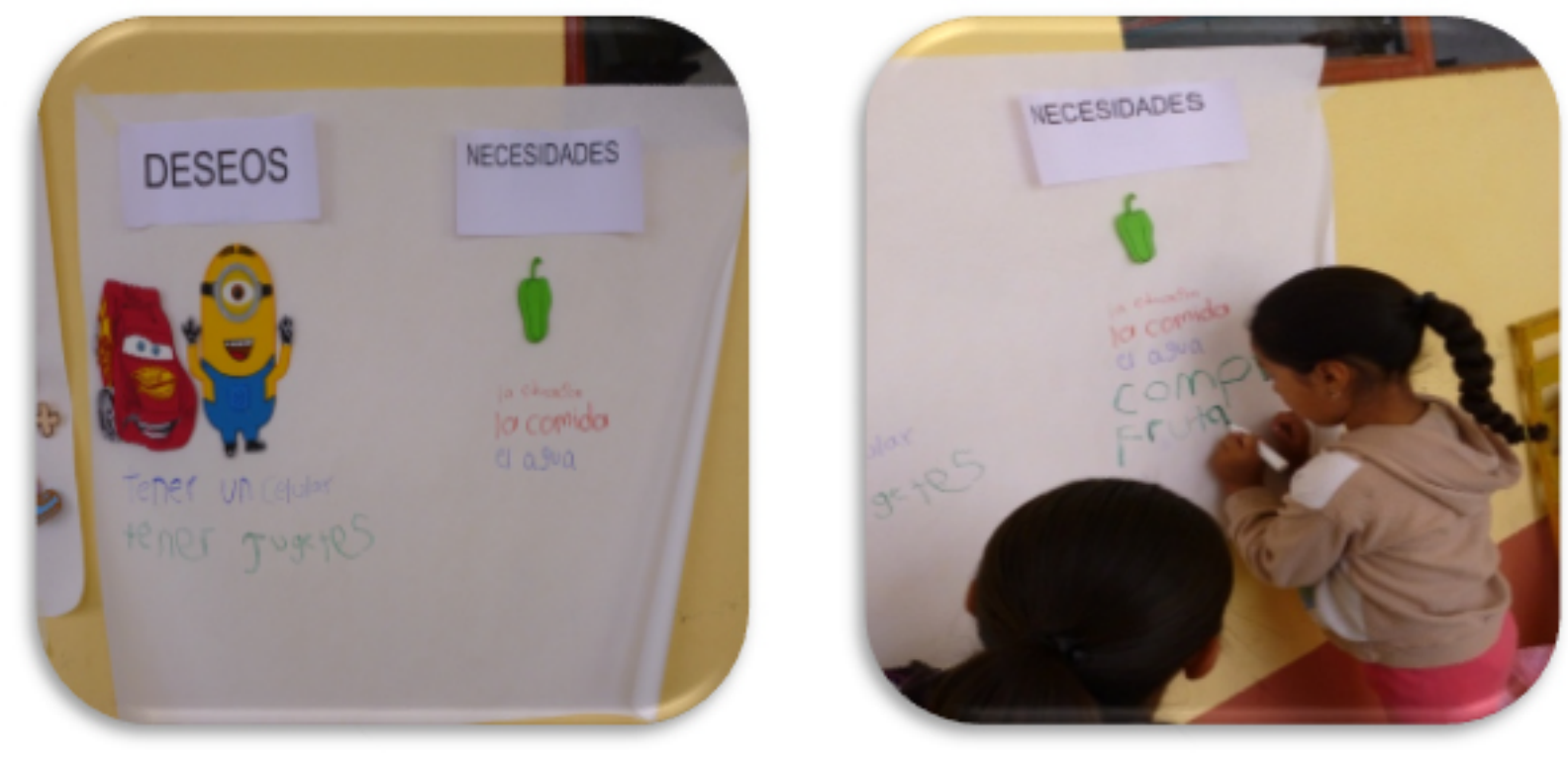

Fuente: trabajo de campo realizado en 2013-2014. Source: Field work carried out in 2013-2014.

Figura 4. Taller de educación financiera y reunión quincenal. Figure 4. Financial education workshop and fortnight meeting.

ahorrando hasta cuando sean adultos, mostrando con ello lo importante que es para ellos la actividad del ahorro. Esta situación está en concordancia con lo encontrado por Guevara et al. (2009), quienes mencionan que el nivel de escolaridad tiene un impacto directo en el ahorro promedio de las familias, asociado esto probablemente a que los hogares modifican sus decisiones de consumo-inversión y esquemas de manejo del riesgo conforme tienen mayor nivel educativo. Respecto a sus expectativas para cuando crezcan, 38 afirmaron que sí esperan terminar una carrera, mientras que el resto señaló que pensaban que no podrían concluirla.

De manera complementaria, se averiguó si conocían a la Fundación Ayú, resultando que la gran mayoría, 35 de ellos, no sabe lo que es, pero hubo siete casos en que dijeron saberlo. Sus respuestas fueron en cuatro casos un grupo de ahorradores, pero dos niños mencionaron que es una sociedad que apoya a los mixtecos; uno más mencionó que representa una ayuda para las familias de la mixteca. Se quiso abordar el tema de si los nińos habían participado en algún proyecto de la Fundación Ayú adicional a ser Chispita, y la respuesta generalizada fue que no habían participado.

Partiendo de la consideración de que los niños ahorran en función de los recursos que les aportan schooling has a direct impact on the average savings of families, with this probably being associated to the households modifying their decisions regarding consumption-investment and schemes of risk management, as they acquire a higher educational level. With regards to their expectations for when they are older, 38 stated that they do expect to finish their undergraduate studies, while the rest pointed out that they thought they would not be able to.

Complementarily, they were asked if they knew about Fundación Ayú, and it resulted that most of them (35) do not know what it is, although there were seven cases when they stated that they did know about it. Their responses were: in four cases, a group of savers, although two boys mentioned that it is a society that supports Mixtec people; one other mentioned that it represented support for families in the Mixtec Region. We attempted to address the issue of whether the children had participated in any project by Fundación Ayú, in addition to being a Chispitas member, and the generalized response was that they had not participated.

Stemming from the consideration that children save in function of the resources that their parents give to them, they were asked what was amount of money that each one of them saved every fortnight 
sus padres, se les preguntó cuál era el monto de dinero que ahorraba cada uno de ellos de manera quincenal de acuerdo con el esquema establecido por la caja. El mayor monto de ahorro fue de $\$ 200.00$, pero solo lo mencionó un entrevistado (2\%); el siguiente es de 25, 30 y 15 pesos (36\%), \$50.00, (19\%) y, finalmente, 100,40 y 20 pesos (30\%), y 10 pesos $(14 \%)$. De los datos anteriores tenemos un máximo de ahorro reportado de $\$ 200.00$, un mínimo de $\$ 10.00$ y un promedio de $\$ 39.29$ pesos a la quincena. La importancia radica no en la cantidad de dinero ahorrado cada quincena, sino en la disciplina y perseverancia con la que lo están realizando.

En el taller se les preguntó a los entrevistados si sabían de dónde venía el dinero para el ahorro, a lo que todos contestaron que provenía del trabajo de papá o mamá, lo cual está en relación con las respuestas a la pregunta que les pedía mencionar tres formas en que los adultos ganaban dinero, siendo la más citada el trabajo, seguida de la venta de algún producto, que finalmente es uno de las labores que desempeñan los padres. Los ahorros de niños y nińas Chispitas se incorporan a lo que concluyen Boza y Zabaleta (2012) al señalar que "se estima que existen más de 2000 millones de personas pobres y desbancarizadas en el mundo, y que todas necesitan ahorrar. Gracias a la creatividad e iniciativa humana las personas sin banco consiguen ahorrar"

La educación financiera es un aprendizaje que pueden iniciar en casa ya que, aunque considerada como educación informal, la disciplina del ahorro en los adultos es una forma que permea los hábitos de quienes tienen menos edad en el hogar. Por ello se les preguntó quién les había inculcado el hábito del ahorro y los resultados resaltan la importancia de la participación de las mujeres, madres de familia, ya que la primera respuesta fue que la mamá es quien les enseñó a ahorrar (67\%); sin embargo, a esta cifra pudiera sumarse la segunda respuesta, en la que se menciona que papá y mamá enseñaron a ahorrar (24\%). Otras respuestas incluyen que fue un familiar distinto (abuelos o tíos), con $7 \%$, mientras que la última mención, con un porcentaje mínimo, corresponde a la figura paterna como ejemplo de disciplina en el ahorro y como motivador para efectuarlo (2\%). En el taller de educación financiera los niños identificaron que el dinero no viene de los árboles o que no se los regalan los bancos, sino que viene del trabajo de sus padres. Lo expone Dolores Alejandra: according to the scheme established by the fund. The highest amount was $\$ 200.00$, but only one of the interviewees mentioned it (2\%); then, 25, 30 and 15 pesos (36\%), \$50.00 (19\%), and finally, 100, 40 and 20 pesos $(30 \%)$, and 10 pesos $(14 \%)$. Of these data we have a maximum amount of savings reported of $\$ 200.00$, a minimum of $\$ 10.00$, and an average of $\$ 39.29$ pesos every fortnight. The importance lies not in the amount of money saved every fortnight, but in the discipline and perseverance with which they are doing it.

In the workshop, the interviewees were asked whether they knew where the money for savings came from, to which they all responded that it was from their father or mother's work, which is related to the responses to the question that asked them to mention three ways in which adults earned money, with work being mentioned more often, followed by the sale of a product, which in the end is one of the tasks that the parents carry out. Savings by Chispitas boys and girls are incorporated to what Boza and Zabaleta (2012) conclude, when they point out that "it is estimated that there are more than 2000 million poor people in the world without access to banks, and they all need to save. Thanks to the creativity and human initiative, people without banks manage to save".

Financial education is a knowledge that can begin at home, since, although considered as informal education, the discipline of saving in adults is a way in which the habit pervades to those who are younger in the household. Therefore, they were asked who had instilled in them the habit of saving, and the results highlight the importance of the participation of women, mothers of the family, since the first answer was that the mother is the one who taught them to save $(67 \%)$; however, the second answer could be added to this figure, where they mentioned that it was mother and father who taught them to save $(24 \%)$. Other responses included that it was a different member of the family (grandparents or aunts/uncles), with $7 \%$, while the last response, with minimum percentage, corresponds to the father figure as example of discipline in savings and as motivator to carry it out $(2 \%)$. In the financial education workshop, the children identified that money doesn't grow on trees and that the banks don't give it out, but rather that it comes from their parents' efforts. Dolores Alejandra describes: 
Vivo en San Isidro Jaltepetongo. Tengo 13 años y estoy en segundo de secundaria. Cada quincena ahorro 10 pesos, mi mamá me enseñó. Me gusta ahorrar porque así puedo comprar mis útiles, quiero viajar a la ciudad de México y también pagar mis uniformes. Yo creo que es importante hacerlo porque de ahí podemos comprar nuestros útiles (Dolores Alejandra. Chispita de la Caja de San Isidro).

Continuando con el tema de la educación financiera, de todos los entrevistados solo ocho saben lo que significa que su dinero gane interés y esos mismos tienen claro que eso pasa con el suyo en la caja. De manera sencilla explican que ganar interés significa que el dinero que ahorran se hace más, por lo que cuando realizan el balance de la caja les dan sus ahorros y algo más de dinero, que representa el interés ganado. La identificación de distintos lugares en que el dinero puede ser guardado fue una de las preguntas del taller de educación financiera, resultando los sitios más señalados en primer lugar la caja de ahorro con 34 menciones y, en segundo término, los bancos con ocho.

Una manera de enseñar a niños y nińas el hábito del ahorro es la participación de los adultos en esquemas de ahorro, como son las cajas de los adultos de la Fundación Ayú. Por esta razón se identificó que en todos los casos era el papá o la mamá de los Chispita quienes participan de manera activa como socios $\mathrm{y}$, en algunos casos, como parte de los comités, en ambas cajas de ahorro de los adultos. Tal y como señalan Vargas y Arán (2014), la calidad de la parentalidad (entendida como las actividades que realizan el padre y la madre en el proceso de cuidado, socialización, atención y educación de hijos e hijas) es un factor que contribuye de manera significativa al desarrollo cognitivo de hijos e hijas. Esta situación está en concordancia con lo señalado por Conde (1998), quien argumenta que el ahorro de las familias está basado en decisiones que toman de manera premeditada los integrantes del hogar para garantizar su consumo futuro a través de la certeza de un ingreso o la adquisición de activos que mejoren su propio bienestar.

De manera complementaria se cuestionó a niños y niñas en cuanto a lo que pensaban sobre el hecho de que algunas personas tenían más dinero que otras. Las respuestas estuvieron divididas, 27 personas refirieron que el principal generador de dinero es el trabajo, pero resulta interesante cómo niños y niñas
I live in San Isidro Jaltepetongo. I am 13 years old and I am studying second year of secondary. Every fortnight I save 10 pesos, my mother taught me. I like to save because that way I can buy my school supplies, I want to travel to Mexico City, and also to pay for my uniforms. I think it is important to do it because we can buy our supplies with that (Dolores Alejandra. Chispitas member from the San Isidro fund).

Continuing with the subject of financial education, of all those interviewed only eight know what it means that their money earns interest, and they are the ones who understand that this is what happens to their money in the fund. In simple terms, they explain that earning interest means that the money they save becomes more, so that when the fund is balanced they give them their savings and some more money, which represents the interest gained. Identifying different places where money can be saved was one of the questions in the financial education workshop, and the places more often mentioned were, first, the savings funds with 34 mentions, and in second, banks with eight.

A way to teach boys and girls the habit of saving is the participation of adults in savings schemes, such as the funds for adults from Fundación Ayú. Therefore, it was identified that in all cases it was the father or the mother of the Chispitas member who participated actively as partners and, in some cases, as part of the committees, in both savings funds for adults. As Vargas and Arán (2014) point out, the quality of parenting (understood as the activities that the father and the mother perform in the process of caring, socialization, attention and education of sons and daughters) is a factor that contributes significantly to the cognitive development of sons and daughters. This situation is in agreement with what was pointed out by Conde (1998), who argues that saving in families is based on decisions that the members of the household make in a premeditated way, to guarantee their future consumption through the certainty of an income or acquisition of assets to improve their own wellbeing.

In a complementary way, boys and girls were asked about what they thought about the fact that some people had more money than others. The responses were divided, 27 people said that the main generator of money is work, but it is interesting to 
identifican que el ahorro es otra fuente de incremento de los recursos.

Castillo (2012) refiere que el ahorro es, dentro de otros, un elemento generador de previsión, ya que cuando se logra acumular una pequeña cantidad, los ahorradores definen mejor qué quieren hacer con su dinero. Con mucha frecuencia, ellas y ellos mismos establecen una finalidad para su ahorro $y$, aunque los pobres viven al día y, por lo tanto, no pueden planear el futuro, con un mínimo ahorro esta situación cambia. Esto no impide que ante una emergencia tengan que retirar el ahorro que pensaban utilizar en otra cosa. En otras palabras, el ahorro introduce una cultura de la planeación que incidirá en cómo satisfacer las necesidades más básicas que de otra forma no serían cubiertas.

El ahorro de los Chispita es uno de los rasgos importantes de la experiencia que se analiza. Una explicación del interés de padres y madres sobre el ahorro de niños y niñas podría ubicarse en formas alternativas para prevenir necesidades futuras. Bazán y Saraví (2012) resaltan cómo las mujeres para administrar el hogar consideran dos rangos de necesidades: la atención a la vida cotidiana, para la que utilizan el dinero que reciben o el que ganan, y otras exigencias que no son inmediatas y que les requiere contar con dinero disponible en determinadas épocas y situaciones (ingresos escolares, enfermedades, y otras emergencias). Este segundo nivel de necesidades se podría resolver accediendo a préstamos a partir de las cuentas de ahorro de niños o niñas. De esta forma las cajitas tienen una doble finalidad: enseñarles a ahorrar y servir de seguro para las emergencias.

Además de ahorrar, los niños tienen otras razones que fortalecen su gusto por estar dentro del grupo Chispitas; para 15 de ellos lo más importante es que es una manera de ahorrar, pero otros refieren que también en ocasiones van de paseo a otros lugares. En las reuniones quincenales se divierten, aunado a que con cierta periodicidad la fundación les envía cajitas de leche.

\section{ConClusiones}

El uso de las microfinanzas como estrategia para reducir la pobreza se ha extendido en los últimos 30 años, a partir de que se formalizaron las iniciativas propuestas por Mohammed Yunus y, aunque las evidencias respecto al impacto en el abatimiento de la pobreza no son contundentes ya que hay una gran variedad de opiniones, desde las que han encontrado see how boys and girls identify that saving is another way to increase resources.

Castillo (2012) refers that saving is, among others, an element that generates foresight, since when a small amount can be accumulated, the savers define better what it is that they want to do with their money. Quite frequently, they establish an aim for their savings, and although the poor live hand to mouth and, therefore, cannot plan the future, with minimum savings this situation changes. This does not impede the fact that in face of an emergency they have to withdraw the savings that they had planned to use for something different. In other words, saving introduces a culture of planning that will have an influence on how to satisfy the most basic needs that otherwise would not be covered.

Savings by Chispitas is one of the important features of the experience analyzed. One explanation of the interest that fathers and mothers show regarding saving by boys and girls could be located in alternative ways of anticipating future needs. Bazán and Saraví (2012) highlight how women, in order to manage the household, consider two ranks of needs: attention to daily life, for which they use the money they receive or earn, and other demands that are not immediate and which require having money available at certain times of the year and situations (school entry, sickness, and other emergencies). This second level of needs could be solved by gaining access to loans from the savings funds of the boys or girls. Thus, the children's savings funds have a double purpose: to teach them to save and to serve as insurance for emergencies.

In addition to saving, children have other reasons that strengthen their appreciation for belonging to the Chispitas group; for 15 of them, the most important aspect is that it is a way to save, but others mention that sometimes they also go on visits to other places. In the fortnight meetings they have fun, and sometimes the Fundación sends them small milk boxes.

\section{Conclusions}

The use of microfinances as a strategy to reduce poverty has expanded in the last 30 years, since the initiatives of proposed by Mohammed Yunus were formalized and, although the evidences regarding the impact on the reduction of poverty are not conclusive since there is a large variety of opinions, from those 
que los microcréditos sí reducen la pobreza, que permite generar mayores ingresos, que reduce la vulnerabilidad a la pobreza de los hogares o que empodera a las mujeres, existen otras opiniones que refieren que utilizar las microfinanzas es como poner una bandita en una cirugía mayor, e incluso, que es una manera de mantener el statu quo del neoliberalismo. Zapata et al (2003) mencionan que son pocos los estudios sobre los procesos de empoderamiento relacionados con el ahorro y crédito, por lo que aún hay vacíos relacionados con los factores que promueven o inhiben este proceso en los usuarios.

Sea cual sea la postura que se tome al respecto, es conveniente analizar cómo una estrategia emprendida desde la sociedad civil, haciendo microfinanzas que pueden considerarse incluso informales, ha influido en varios aspectos, como la percepción de que el ahorro de los Chispitas no es solo cosa de niños, ya que la participación de los padres, la disciplina quincenal de asistir a las reuniones y de aportar su ahorro permea en que niños y niñas vean el ahorro como algo normal en sus vidas $y$, aun a su muy corta edad puedan, en algunos casos, establecer objetivos o metas para usar sus ahorros.

La operación de las cajas tiene gran influencia en la reducción de los costos de transacción de los adultos, ya que los requisitos de ingreso son mínimos. Para los niños no hay requisitos y la tasa de interés tanto activa como pasiva es propuesta y aprobada por todos los integrantes de las cajas y no resulta onerosa comparada con microfinancieras que operan en la formalidad en la región. Las personas no incurren en gastos de traslado, ya que la mayoría llega caminando al lugar de reunión, con un máximo de tiempo invertido de 30 minutos. Las cajas no tienen gastos de administración, ya que la participación de las mujeres en el comité es a título honorífico, no tienen un sueldo, no requieren de instalaciones especiales ni local exprofeso; al reunirse en la plaza cívica de ambas localidades, tampoco existen gastos por ejecutivos o personal de promoción o cobranza. Otro tema importante es el papel que cumplen las cajas de ahorro como fuente de inclusión financiera para los habitantes de las localidades en las que se ubican. Aunque los servicios que se ofrecen son solo ahorro y crédito, esto permite a los usuarios tener acceso a ellos a costos razonables. Algunos autores mencionan que un mayor acceso de los grupos poblacionales de menor ingreso a los servicios financieros that have found that microcredits do in fact reduce poverty, that they allow generating greater income, that they reduce the vulnerability of households to poverty or empower women, there are other opinions that refer that using microfinances is like placing a band aid on a major surgery, and even, that they are a way of maintaining the statu quo of Neoliberalism. Zapata et al. (2003) mention that there are few studies about the empowerment processes related with savings and credit, so there are still gaps related to the factors that promote or inhibit this process in users.

Whichever the posture may be in this regard, it is convenient to analyze how a strategy undertaken from the civil society, creating microfinances that could even be considered informal, has had an influence on several aspects, such as the perception that savings by the Chispitas is not just child's play, since participation by parents, the discipline every fortnight to attend meetings and contribute their savings pervades the boys and girls as they consider saving as something normal in their lives and, even at their very short age, they can, in some cases, establish objectives or goals to use their savings.

The operation of the funds has great influence on the reduction of transaction costs for adults, since the requirements for income are minimal. For the children there are no requirements and the interest rate, both active and passive, is proposed and approved by all the members of the funds and is not onerous compared to micro-financers that operate formally in the region. The people do not incur in transportation costs, since most can reach the meeting place by walking, with a maximum of time invested of 30 minutes. The funds do not have administration costs, since women's participation in the committee is with an honorary title, they do not have a wage, do not require special facilities or a property purposely built for it; by meeting in the civic plaza of both localities, there are also no expenses for executives or staff for promotion or debt collection. Another important issue is the role that the savings funds have as a source of financial inclusion for inhabitants in the localities where they are located. Although the services they offer are only saving and credit, this allows the users to have access to these at reasonable costs. Some authors mention that greater access of population groups of lower income to financial services could contribute to decreasing poverty and to a better distribution of income. 
puede contribuir a la disminución de la pobreza y a una mejor distribución del ingreso.

Un tercer aspecto rescatable de las cajas de ahorro es la educación financiera que se impulsa en los nińos, ya que al predicar los padres con el ejemplo, sus hijos desde pequeños observan la disciplina de las mujeres, y ocasionalmente de los padres, de reservar cierta cantidad de sus ingresos y asistir a depositar su ahorro de manera puntual en las reuniones de las cajas. En sus pláticas cotidianas escuchan hablar de los intereses que su dinero gana, así como de los que deben pagarse por concepto de los préstamos recibidos; de igual manera, en las familias se habla del destino que le darán a los ahorros o de la necesidad de ahorrar para enfrentar gastos, como los escolares, o por enfermedades o emergencias. Este tipo de prácticas genera un espacio de participación familiar ya que, aunque el ahorro proviene de los padres, se genera una actividad en común, pero también individual. Finalmente, como señala Castillo (2012), una estrategia de ahorro específica puede convertirse en espacio de permanente aprendizaje, independiente del nivel escolar que se tenga, ya que la práctica lleva implícita una serie de valores que al paso del tiempo construirán una cultura no solo del ahorro, sino de la participación, la legalidad, de rendición de cuentas, de confianza y de corresponsabilidad.

Un cuarto rubro que resulta importante hacer notar es que, como menciona la UNICEF, la exclusión de servicios y bienes esenciales, como la alimentación adecuada, la atención de la salud y la escolarización, afecta la capacidad de los menores para participar en sus comunidades y sociedades tanto ahora como en el futuro. Al igual que las dimensiones de la exclusión, existen factores que se superponen y se vinculan entre sí, cada uno de ellos agravando el siguiente hasta que en los extremos algunos niños y niñas excluidos se transforman en invisibles cuando se les niegan sus derechos, cuando pasan completamente desapercibidos en sus comunidades, cuando no pueden acudir a la escuela o cuando están lejos del alcance de las autoridades, debido a su ausencia en las estadísticas, en las políticas y en los programas. Ante este panorama es probable que la participación de los niños en las cajas de ahorro pudiera ser un elemento de reducción del riesgo de que ellos y ellas se vuelvan "invisibles" por la violación de sus derechos, que los excluyen socialmente al incorporarse como socios con todos los derechos que eso representa y con el reconocimiento
A third aspect that is worth rescuing about the savings funds is the financial education that is promoted in the children, since when the parents teach by example, their children observe the women's discipline from a young age, and occasionally the father's, of putting aside a certain amount of their income and attending to deposit their saving promptly at the meetings of the funds. In their daily conversations they listen to talk about the interests that the money wins, as well as those that should be paid per concept of the loans received; likewise, in the families there is talk about the destination that they will give their savings or the need to save to face expenses, such as school supplies, or from disease or emergencies. This type of practices generates a space for family participation which, even when the savings are from the parents, generates an activity in common, but also an individual one. Finally, as Castillo (2012) points out, a specific savings strategy can become a permanent learning space, regardless of the level of schooling that they have, since the practice carries implicitly a series of values that with time will build a culture not only of saving, but of participation, legality, accountability, trust and coresponsibility.

A fourth area that is important to make a note of is, as the UNICEF mentions, the exclusion of services and essential goods, such as the appropriate diet, attention to health and schooling, affects that capacity of the children to participate in their communities and societies both now and in the future. Like the dimensions of exclusion, there are factors that are superposed and linked between them, each one worsening the next one until in the extremes some excluded boys and girls are made invisible when their rights are denied, when they go completely unnoticed in their communities, when they cannot attend school, or when they are far from the reach of authorities due to their absence from statistics, policies and programs. Facing this panorama, it is likely that the participation of children in the savings funds could be an element to reduce the risk of them becoming "invisible" from the violation of their rights, which excludes them socially when becoming involved as partners with all the rights that this represents, and with the recognition that the society of their community grants them, since with their savings they can even finance the loans for their parents and other adults in 
que la sociedad de su comunidad les otorga, ya que incluso con sus ahorros pueden financiar los préstamos para sus padres y otros adultos de la localidad. En este sentido, y siguiendo a Díaz (2010), la participación de niños, niñas y adolescentes en las cajitas puede ser una posibilidad para que sean incluidos en los espacios de la vida social, teniéndolos en cuenta como actores y actrices con propuestas que se integren con protagonismo en el contexto en que viven y que les permita, como sugieren Gómez y Alzate (2014), convertirse en actores sociales sujetos de pleno derecho, rompiendo el adultocentrismo que ha prevalecido históricamente.

El anterior razonamiento fundado en que niñas, niños y adolescentes pertenecen a un grupo poblacional que históricamente ha sido tutelado bien por la autoridad de los padres o por la del Estado, asumiendo la idea de que solo por su edad son personas incapaces de tomar decisiones, por quienes debe tomarse la palabra cuando tienen algo que decir. Esta limitante frente a los adultos ubica a los niños como parte de los sectores de la población más vulnerables de ser discriminados en menoscabo del ejercicio de sus derechos, situación que se agrava aún más si como rasgos adicionales que abonan a la discriminación se agregan el hecho de no tener dinero, su apariencia física, la edad y el género, exacerbado además por características intrínsecas de la región en que habitan, como haber nacido en un entorno con bajo nivel de escolaridad, pertenencia a etnias o hablante de lenguas distintas, lo que nos evidencia un país desigual que genera ciudadanos distintos, por la única razón de haber nacido en cierta región geográfica. Lo anterior se evidencia cuando a los niños Chispitas se les preguntó cómo consideraban a sus familias, en una escala de muy pobre, pobre, ni rica ni pobre, rica y muy rica, ubicándose $92 \%$ de las respuestas en el centro, es decir, ni rica ni pobre; el restante $8 \%$ se considera integrante de una familia pobre. Como punto final, puede decirse que la educación financiera enseñada desde edades tempranas tendrá un impacto permanente para toda la vida; incluso puede abonar a ser la respuesta para que las familias rompan con ciclos de endeudamiento y, en el mejor de los casos, con el círculo de la pobreza.

\section{Literatura Citada}

Amar, Amar José, Marina Llanos Martínez, Raymundo Abello Llanos, y Marianela Denegri Coria. 2003. Desarrollo del the locality. In this sense, and following Díaz (2010), the participation of boys, girls and teenagers in the children's savings funds could be a possibility for them to be included in the spaces of social life, taking them into account as actors with proposals that are integrated with prominence into the context that they live in, and which allows them, as Gómez and Alzate (2014) suggest, to become social actors subject to full rights, breaking the adult-centrism that has prevailed historically.

This reasoning based on the girls, boys and teenagers belonging to a population group that has been well-tutored historically by the authority of parents or by the State, assuming the idea that solely because of their age they are people incapable of making decisions, for whom they must speak when they have something to say. This limitation in face of adults places the children as part of the sectors of the population most vulnerable to be discriminated in detriment of the exercise of their rights, situation that is further aggravated if, as additional features that contribute to discrimination, the fact of not having money is added, as well as physical appearance, age and gender, additionally exacerbated by intrinsic characteristics of the region where they inhabit, such as having been born in an environment with low schooling level, belonging to ethnic groups or speaking different languages, which makes evident an unequal country that generates different citizens, for the only reason of having been born in certain geographical region. This is evidenced when the Chispitas children were asked how they considered their families, in a scale of very poor, poor, neither rich or poor, rich, or very rich, with $92 \%$ of the responses located in the center, that is, neither rich nor poor; the other $8 \%$ considers they are members of a poor family. As final point, it can be said that financial education taught from early ages will have a permanent impact for their whole life; this can even contribute to being the response for the families to break with cycles of indebtedness and, in the best of cases, with the circle of poverty.

- End of the English version -

pensamiento económico en niños de la región Caribe colombiana. In: Revista Latinoamericana de Psicología, vol. 35, núm. 1.

Banamex-UNAM. 2008 Primera encuesta sobre cultura financiera en México. 
Bazán Levy, Lucía, y Gonzalo A. Saraví. 2012. La monetarización de la pobreza. Estrategias financieras de los hogares mexicanos. México: Ciesas, Publicaciones de la Casa Chata.

Bernal Lara, Pedro, 2007. Ahorro, crédito y acumulación de activos en los hogares pobres de México. Cuadernos del Consejo de Desarrollo Social No. 4. Consejo de Desarrollo Social de Nuevo León.

Boza, Chirino José, y José Ignacio Zabaleta. 2012. La riqueza de los pobres. Los Microahorros. In: Revista Atlántica de Economía-Volumen 1-2012.

Campos Bolaños, Pilar. 2005. El ahorro popular en México: acumulando activos para superar la pobreza. México, Miguel Ángel Porrúa/CIDAC.

Carbajal, G. Javier. 2008. Educación financiera y bancarización en México. Documentos de Trabajo No. 8 CEEDE.

Castillo, Alfonso. 2012. Ahorro, vulnerabilidad y estrategias de desarrollo. Un caso en México. MBS. No 2

Centro para la Inclusión Financiera en ACCION International. 2009. Perspectivas para México de Inclusión Financiera Integral. Informe oficial del Proyecto de Inclusión Financiera en 2020 .

CNIF (Consejo Nacional de Inclusión Financiera). 2013. Reporte de Inclusión financiera 5, 2013. Disponible en http:// www.cnbv.gob.mx/Inclusi\%C3\%B3n/Documents/Reportes $\% 20 \mathrm{de} \% 20 \mathrm{IF} /$ Reporte $\% 20 \mathrm{de} \% 20$ Inclusion $\% 20$ Financiera\%205.pdf (consultado el 5 de marzo, 2015)

CNVB (Comisión Nacional Bancaria y de Valores). 2015. Misión y visión. Disponible en http://www.cnbv.gob.mx/ CNBV/Paginas/Misi\%C3\%B3n-y-Visi\%C3\%B3n.aspx (Consultado el 11 de marzo, 2015)

Coates, Kenneth. 2009. Educación Financiera: Temas y Desafíos para América Latina. Conferencia Internacional OCDE-Brasil sobre Educación Financiera. Rio de Janeiro, Diciembre 1516, 2009: http://www.oecd.org/dataoecd/16/20/44264471. pdf Consultado el 10 de Febrero, 2015)

Conapo (Consejo Nacional de Población). 2010. Grado de marginación por municipio 2010. Consultado el 28 de Julio de 2014. In: http://www.conapo.gob.mx/work/models/CONAPO/indices_margina/mf2010/CapitulosPDF/ Anexo\%20B3.pdf

Conde Bonfil, Carola. 1998. Ahorro familiar y sistema financiero en México. Tesis Doctoral. UAM.

Delval, Juan. 1983. Crecer y Pensar. La construcción del conocimiento en la escuela. Cuadernos de Pedagogía. Editorial Laia. Barcelona, España.

Delval, Juan. 1989. La construcción de la representación del mundo social en el niño. In: Enesco, 1., Turiel, E. y Linaza, J. (eds). El mundo social en la mente de los niños. Madrid: Alianza Editorial.
De la Madrid, Ricardo Raphael. 2012. (coord). Reporte sobre la discriminación en México 2012 Crédito. CIDE. Consejo Nacional para Prevenir la Discriminación.

Díaz, Silvia Paulina. 2010. Participar como niña o niño en el mundo social. Revista Latinoamericana de Ciencias Sociales, Niñez y Juventud [en línea] 2010, 8 (Julio-Diciembre): [Fecha de consulta: 11 de marzo de 2015] Disponible en:<http://www.redalyc.org/articulo.oa?id=77315155026>

Esquivel Martínez, Horacio. 2008. Situación actual del Sistema de Ahorro y Crédito Popular en México. In: Problemas del Desarrollo, enero-marzo, vol. 39, 152. pp: 165-191.

FAO (Food and Agriculture Organization). 2013. Manual de consulta sobre el ahorro de grupo. Consultado el 5 de marzo de 2015. In: http://www.fao.org/docrep/005/y4094s/ y4094s04.htm

Gómez Mendoza, Miguel Angel, y María Victoria Alzate-Piedrahíta. 2014. La infancia contemporánea. Revista Latinoamericana de Ciencias Sociales, Niñez y Juventud, 12 (1).

Guevara Sanginés, Alejandro, Luis Rosendo Gutiérrez, Omar Stravidis, y José Alberto Lara. 2009. Microahorro y Educación. Universidad Iberoamericana.

Heimann, Ursula, Juan Navarrete Luna, María O’Keefe, Beatriz Vaca Domínguez, y Gabriela Zapata Álvarez. 2009. Mapa Estratégico de Inclusión Financiera: Una Herramienta de Análisis. El Nido, México

INEGI (Instituto Nacional de Estadística, Geografía e Informática) 2012. Información de México para niños. Consultado el 1 de Agosto de 2014. In: http://cuentame.inegi.org.mx/ monografias/informacion/oax/poblacion/_

Mansell Carstens, Catherine. 1995. Las finanzas de los populares en México: el redescubrimiento de un sistema financiero olvidado. México, ITAM.

OECD .2005. Improving Financial Literacy: Analysis of Issues and Policies. Paris.

Rutherford, Stuart. 2002. Los pobres y su dinero. México: La Colmena Milenaria/Universidad Iberoamericana.

Sherraden, Michael, Mark Schreiner, Margaret Clancy, Lissa Johnson, Jami Curley, Michal Grinstein-Weiss, Min Zhan, and Sondra Beverly. 2001. Savings and Asset Accumulation in Individual Development Accounts. Center for social Development, Reporte de Investigación.

Vargas, Rubilar Jaen, y Vanessa Arán Filippetti. 2014. Importancia de la Parentalidad para el Desarrollo Cognitivo Infantil: una Revisión Teórica. In: Revista Latinoamericana de Ciencias Sociales, Niñez y Juventud, 12 (1). pp: 171-186.

Zapata, Martelo Emma, Verónica Vázquez García, Pilar Alberti M., Elia Pérez N., Josefina López Z., Aurelia Flores Hernández, Nidia L. Hidalgo Celarié, y Laura Elena Garza Bueno. 2003. Microfinanciamiento y empoderamiento de mujeres rurales. Las cajas de ahorro y crédito en México, México: Plaza y Valdés y Colegio de Postgraduados. 